\title{
Paradigms of historical development: the Raccolta Aragonese, Landino, and Bembo's Prose.
}

\section{Maria Clotilde Camboni}

\begin{abstract}
This article analyses the relationship of Pietro Bembo's Prose with the introductory Epistola of the Raccolta Aragonese and Cristoforo Landino's proemio to his Comento sopra la Comedia, with regard to their views of the previous vernacular tradition and in particular the more or less comparable paradigms applied to past literary history. The question of whether Bembo knew Poliziano's Epistola is investigated, and the similarities and dissimilarities between the different narratives concerning cultural development and the ways in which these narratives are elaborated in the three texts are evaluated.
\end{abstract}

In Martin McLaughlin’s formulation, Pietro Bembo’s Prose “proceed to transfer Bembo’s Latin Ciceronianism to the volgare. The written works of Boccaccio and Petrarch, the vernacular equivalents of Cicero and Virgil, are for Bembo the sole models in the new language. But Ciceronianism underlies the Prose in another way too. Bembo notes that the full cycle of Golden Age (the Augustan era), Decline (the Middle Ages), and Revival (Bembo's lifetime) has taken place in Latin, leading to the triumph of Ciceronianism, whereas the vernacular after the Golden Age of Petrarch and Boccaccio has only reached the stage of Decline... . Here Bembo is imposing the humanist Latin model of Golden Age-Decline-Revival on the literature of the Italian vernacular, and making each of those stages correspond respectively to the three centuries, Trecento, Quattrocento, and Cinquecento. This influential model replaces the previous paradigm established in the Quattrocento by Bembo's predecessors, Landino, Poliziano, and Lorenzo, who had purveyed 
a dynamic model of the development of the vernacular, moving from birth in the Trecento to adolescence in the Quattrocento, and predicting maturity in the future."1

This summation of Bembo's operation is unquestionable. However, its relationship with the previous paradigms can be detailed more thoroughly, especially regarding the Laurentian Florence ones. The aim of this study is to explore Bembo's Prose relationships with two texts which apply to the development of the vernacular a model that seems to be quite different to the metaphor of growth from infancy to maturity used by Lorenzo de' Medici in his Comento and recalled by McLaughlin: ${ }^{2}$ the introductory Epistola of the Raccolta Aragonese, the dedicatory letter probably written by Agnolo Poliziano which opened the collection of vernacular poetry sent around the year 1477 by Lorenzo de' Medici to Federico d'Aragona, the younger son of the king of Naples; and Cristoforo Landino's proemio to his Comento sopra la Comedia, published in 1481.

It is well known that in writing his Prose Bembo exploited Dante's De vulgari eloquentia, in particular to reconstruct the distant poetic past, and the influence of the De vulgari on the Prose has received some treatment. ${ }^{3}$ The same cannot be said for other texts that trace a history of vernacular poetry, or a history of poetry where vernacular poets are represented alongside Latin ones, such as the above-mentioned Epistola on the one hand and Landino's Proemio on the other, despite the fact that they were written during Bembo's lifetime, and their authors therefore share a comparable vantage point, quite different to Dante's.

Some scholars have already advanced the hypothesis that Bembo was under the influence of Poliziano's Epistola while writing the Prose. ${ }^{4}$ As far as Landino is concerned, we know for sure that Bembo had a copy of his Comento sopra la Comedia, and therefore that he had access to the proemio to this work. We have in fact his copy, now preserved in Paris, with some annotations in Pietro Bembo's own hand and also in that of his father, Bernardo: the book had been sent to the latter by Landino himself, who also wrote a Latin letter and a poem addressed to him on one of its 
flyleaves. ${ }^{5}$ Pietro Bembo's knowledge of Poliziano's letter accompanying the Raccolta Aragonese is however far from being an indisputable fact. Besides examining the relationship between the Prose and the above-mentioned texts of Laurentian Florence outlining a history of vernacular literature, this article will also investigate whether Bembo really knew Poliziano's Epistola. Above all, however, its main purpose is to weigh the similarities and dissimilarities between their different narratives concerning cultural development, and the ways in which they are elaborated.

The historical models applied to the vernacular in Laurentian Florence besides the "growth metaphor" used in Lorenzo de' Medici's Comento de' miei sonetti seem in fact to anticipate Bembo's paradigm. A multi-level analysis of Bembo's relationship to his predecessors will therefore allow us to set in context his reuse of the Golden Age-Decline-Revival model for vernacular literature.

As we have noted, both Pietro and Bernardo Bembo wrote annotations on the margins of their copy of Landino's Comento. Pietro's annotations mostly tackle philological and linguistic aspects and have been analysed by Carlo Pulsoni. ${ }^{6}$ Several of these, however, less interesting in Pulsoni's perspective and therefore overlooked by him, are similar to those he made in his copy of the $D e$ vulgari, such as the ones that repeat names or data from Landino's text which relate to the previous vernacular tradition. For instance: “Giovanni villani scrittore di chronica fiorentina" (f. 85v); “Guido Guinizzelli” (244r); the first lines of two of Dante's canzoni quoted in the Comento, Voi ch'intendendo (ff. 59 and 300r) and Donne ch'avete (238r). ${ }^{7}$ Such marginalia could be later exploited for assembling records or card-indexes, similar to those commonly compiled from classical texts. ${ }^{8}$ In short, they seem to reveal Bembo's intention of using Landino's Comento as a source for composing works on the vernacular.

Even more interesting are some contacts between the text of Bembo's Prose and Landino's proemio, which occupies the first dozen leaves of the incunabulum. Some of Bembo's arguments in 
fact echo Landino's reasoning. This is the case at the beginning of the first book of the Prose, with Giuliano de Medici's answer to Ercole Strozzi's remark that it might have been better to write in Latin, as Latin was the language held in higher esteem. Giuliano replies that it is not always appropriate to employ the more valued language, and ends by saying that, as vernacular has not yet had many good writers, he who uses it for writing can hope to receive the honours reserved for pioneers, whereas if he uses Latin, he risks being accused of bringing trees to the forest.

con ciò sia cosa che per ciò che questa lingua non per ancora si vede essere molto ricca e ripiena di scrittori, chiunque ora volgarmente scriverà, potrà sperare di meritar buona parte di quella gratia che a' primi ritrovatori si dà delle belle e laudevoli cose; là dove, scrivendo latinamente, a llui si potrà dire quello che a' romani si solea dire, i quali allo scrivere greco si davano, che essi si faticavano di portare alberi alla selva. (Tavosanis 180)

This resonates with what according to Landino is one of the main reasons Dante deserves boundless gratitude, because he was the first to ennoble the vernacular, as no one had done before, succeeding in what no one before had even attempted. In this regard, Landino compares Dante to Homer and Virgil, who had received literary languages already polished and cultivated by their predecessors, in a passage where he also reaffirms his key ideas about the possibility of refining the vernacular and the necessity to achieve such an improvement by means of the close study and imitation of classical authors. Landino had already stated these theories in his prolusione to his lessons about Petrarch's vernacular poetry, more than ten years before the publication of the Comento, elaborating on positions that his older friend and mentor Leon Battista Alberti already held; ${ }^{9}$ in the proemio $^{\circ}$ passage, he seems moreover to react against the somehow belittling judgment on Dante given in Poliziano's Epistola. ${ }^{10}$

... innumere et grandissime gratie gli renderemo, perché fu el primo che la lingua nostra patria insino a' suoi tempi roza inexercitata, et di copia et d'elegantia molto nobilitò, et fecela culta et ornata. Trovò Homero la lingua greca molto già abondante et exculta da Orpheo, et da Museo, et da altri poeti più 
vetusti di lui. Trovò la latina Virgilio già elimata et exornata, et da Ennio, et da Lucretio, da Plauto, et da Terentio, et altri poeti vetusti amplificata. Ma innanzi a Danthe in lingua toscana nessuno havea trovato alchuna leggiadria, né indocto elegantia o lume alchuno; et excepto le rime, benché anchora quelle sieno inepte et roze, niente hanno gl'antichi in che si vegga un minimo vestigio di poeta. Danthe fu el primo che conosciuto ne gli scriptori latini gl'ornamenti e quali sono comuni all'oratore et al poeta, et inteso quanto acuto ingegno è necessario nella inventione poetica, quanto giudicio nella dispositione, quanto varii colori et lumi nella elocutione, preterea di quanti figmenti debba essere velato el poema, et di quanta et quanto varia doctrina referto, tentò con felice auspicio indurre tutte queste chose nella nostra Iingua. Il che ne' passati secoli nessuno havea tentato. Il perchè lui decte principio, lui molto la riduxe inverso la perfectione. Il che rade volte tra' mortali è intervenuto. (Landino, Comento 253)

Another of Landino's remarks that seems to have triggered a reaction in Bembo can be found immediately afterwards in the same proemio - actually in the same ninth chapter, "Life of Dante", on the following page. It concerns Boccaccio, who for Landino was by far inferior to Petrarch, extolled immediately before. Bembo's probable reaction can be found at the end of the second book of the Prose, where, after having established and somehow demonstrated that the two models to imitate are Petrarch for poetry and Boccaccio for prose, Bembo adds that while sometimes Boccaccio was not such a prudent writer, and this applies even in the Decameron, nevertheless he wrote in a graceful way, even the parts of the Decameron that he had not so wisely decided to write.

Che quantunque del Boccaccio si possa dire che egli nel vero alcuna volta molto prudente scrittore stato non sia; con ciò sia cosa che egli mancasse talora di giudicio nello scrivere non pure delle altre opere, ma nel Decamerone ancora; nondimeno quelle parti del detto libro, le quali egli poco giudiciosamente prese a scrivere, quelle medesime egli pure con buono e con leggiadro stile scrisse tutte; il che è quello che noi cerchiamo. (Tavosanis 248 , in the apparatus criticus)

This comment concerning Boccaccio has been added in the margin of the manuscript Vatican 3210, which contains the first stage of the Prose extant and known to us, at the end of the second book, while Bembo was revising the third. ${ }^{11}$ It seems to be an answer to Landino's remark, interpreted as 
a criticism of Boccaccio's choice of subjects. Such moralizing criticism can be found in other authors, ${ }^{12}$ but from a passage of Landino's prolusione to his lessons about Petrarch's vernacular poetry it is clear that Landino's critique does not pertain to the content, but rather addresses the form of Boccaccio's writing, his style, which according to Landino was the most significant aspect.

Né m'è incognito che nella passata età Giovanni Boccaccio, uomo di grande ingegno e di non poche lettere, dette grande aiuto alla fiorentina eloquenzia, ma maggiore sarebbe stato se avessi meno perdonato alla fatica e non si fussi tanto nel dono della natura confidato che nell'arte fussi alquanto negligente.... (Landino, Scritti 35)

Bembo probably refutes an opinion that he misunderstood, since he seems to have interpreted the passage of the proemio to Landino's Comento about Boccaccio in contrast with the immediately preceding praise of Petrarch for never being obscene, and he also seems not to have been aware of Landino's prolusione.

Ma quello in che [Petrarca] obtiene sopra tutti la palma, in ogni lasciva materia, benché sia giocondissimo, nientedimeno observa lieta modestia, né mai diviene obsceno; et nessuno de gl'eloquentissimi negherà trovare in lui, non solo expresse, ma dipincte, molte chose, le quali innanzi giudicava essere impossibile dirle con alchuna elegantia in questa lingua. Sequitò el Boccaccio molto inferiore a lui, ma di poetico ingegno da natura instructo, et d'inventioni molto ornato. (Landino, Comento 254)

It should be observed that in his copy of the Comento Bembo has added a notation on the same page as Landino's remark concerning Boccaccio: the name "Batista Alberto", that is the abovementioned Leon Battista Alberti, repeated in the margin, a name which in Landino's incunabulum appears one line after the end of the remark concerning Boccaccio, in a passage where Landino greatly praises Alberti's qualities as a writer in the vernacular - qualities that will be completely overlooked by Bembo in his Prose, where the only evocation of Alberti focuses on his role as an artist. 
Let us get to the point of these paradigms: in the proemio to the Comento sopra la Comedia, with regard to literature as well as other cultural fields, we are presented with a development where a culminating phase is followed by a decline, and then by a revival, which is totally comparable to the model of Golden Age-Decline-Revival later adopted by Bembo. The main difference is that while in Bembo's perspective the decline took place after Dante and Petrarch, in Landino's reconstruction Dante and Petrarch are the first authors in the post-decline revival of poetry.

Ma di Danthe et del Petrarca diremo in altro luogo. Et qui solamente grandissime infinite et immortali laude riferiremo loro, perché la già molti anni smarrita strada, la quale gl'amanti delle muse guida in Parnaso et al Pegaseo fonte, ritrovorono, et tra pruni et sterpi ricoperta, et per questo incognita, in maniera purgorono, che dipoi da molti è stata pesta. (Landino, Comento 236)

As a matter of fact, the real difference between the two perspectives is that, while in Bembo's case the Golden Age-Decline-Revival model was applied separately to Latin and vernacular, and thus with different chronologies, in Landino's case the same model is applied to poetry in general, independently from the language in which the poetry was written. This allows Landino to have a coherent chronology, the same for art and literature, and therefore to clearly state that both went through a probably contemporaneous decline.

È la eloquentia regina de gl'huomini, ... . non patisce il tempo riferire sue laude. Solo affermo poche chose essere in quella che non sieno comuni al poeta et all'oratore. Crebbono queste due spetie di scriptori crescendo lo 'mperio latino, et vennono al suo colmo in Virgilio et in Cicerone. Dipoi diminuendo quello anchora epse declinorono; et finalmente sobmersa Italia da varie inondationi di barbariche nationi, al tutto perirono. Ma questo ad che proposito? Meffé, accioché buona gratia consequiti da tutta Italia el fiorentino popolo per due cagioni. Prima perché chome in una sua oratione scrive el Petrarca, l'ultimo poeta laureato, che in prezo rimanessi in lingua latina fu el fiorentino Claudiano, et dipoi perché el primo che dopo la resurrexione della facultà poetica prendessi laurea corona fu el Petrarca, perché Danthe dinegò prendere tale honore se non lo prendessi nel baptisterio fiorentino. 
Fu adunque la nostra città l'ultima, nella quale si spegnessi tale facultà, et la prima nella quale si raccendessi. (Landino, Comento 235-36)

Resta la pictura, la quale appresso gl'antichi non fu mai in piccola stima... . Né fu molto antica, perché secondo Plinio ne' tempi delle guerre troiane non si trovavono anchora pictori. E primi in Grecia furono Serdice Corynthio, et Telephane sycionio. Ma Parrasio ephesio la riduxe in grande dignità. Sequitorono dipoi molti da molti lodati, tra' quali el primo grado tiene Apelle da tutti reputato etiam ne' futuri secoli insuperabile. Ma tale arte dopo sua perfectione chome molte altre nell'italica servitù quasi si spense; et erono le pitture in quegli secoli non puncto atteggiate, et sanza affecto alchuno d'animo. Fu adunque el primo Ioanni fiorentino cognominato Cimabue che ritrovò e liniamenti naturali, et la vera proportione, la quale e Greci chiamano symetria, et le figure ne' superiori pictori morte fece vive et di varii gesti, et gran fama lasciò di sè; ma molto maggiore la lasciava, se non havessi havuto sì nobile successore, quale fu Giocto fiorentino coetaneo di Danthe. Chostui fu tanto perfecto et absoluto, che molto dipoi si sono affatichati gl'altri che hanno voluto superarlo. (Landino, Comento 240-41)

Compared with Bembo, this paradigm was therefore applied by Landino in a radically different way, one which puts Latin and vernacular on a perfectly equal level. The author of the Prose, who theorized for the latter the same dignity enjoyed by the former, seems rather to claim such dignity for each language in its own domain. Thus, Bembo reinstates the Golden Age-Decline-Revival model on vernacular literature: as Carlo Dionisotti noted, to be able to succeed in imposing his linguistic codification Bembo had to make a series of literary value judgements that relied on the construction of an historical overview of vernacular literature, ${ }^{13}$ homologous to its Latin counterpart.

The contrast between Bembo's and Landino's approaches is interesting, not least because the idea of linguistic evolution, that according to Mirko Tavoni is an aspect of Bembo's thinking that was influenced by the Epistola,${ }^{14}$ and this is present also in Landino's proemio: 
Ma tornando alla lingua, affermo che chome ne' vetusti secoli prima la lingua greca, dipoi la latina per gran copia di scriptori, e quali di tempo in tempo la ripulirono, di roza et povera divenne elimata, chosì la nostra, et già da hora per la virtù de gli scriptori da me nominati è divenuta abondante et elegante, et ogni giorno, se non mancheranno gli studii, più diventerà. (Landino, Comento 255)

In the passage above the comparison between the two languages, Latin and the vernacular, is also remarkable. The same comparison can in fact be found in the Prose, when at the end of the first book Carlo Bembo states which language must be used by means of an analogous parallel between the evolution of Latin and the vernacular.

Non dovea Cicerone o Virgilio, lasciando il parlare della loro età, ragionare con quello d'Ennio o di quegli altri che furono più antichi ancora di lui; per ciò che essi avrebbono oro purissimo, che delle preziose vene del loro fertile e fiorito secolo si traeva, col piombo della rozza età di coloro cangiato; sì come diceste che non doveano il Petrarca e il Boccaccio col parlare di Dante, e molto meno con quello di Guido Guinicelli e di Farinata e dei nati a quegli anni, ragionare. Ma quante volte aviene che la maniera della lingua delle passate stagioni è migliore che quella della presente non è, tante volte si dee per noi con lo stile delle passate stagioni scrivere, Giuliano, e non con quello del nostro tempo. Perché molto meglio e più lodevolmente avrebbono e prosato e verseggiato e Seneca e Tranquillo e Lucano e Claudiano e tutti quegli scrittori che dopo '1 secolo di Giulio Cesare e d'Augusto e dopo quella monda e felice età stati sono infino a noi, se essi nella guisa di que' loro antichi, di Virgilio dico e di Cicerone, scritto avessero, che non hanno fatto scrivendo nella loro; e molto meglio faremo noi altresì, se con lo stile del Boccaccio e del Petrarca ragioneremo nelle nostre carte, che non faremo a ragionare col nostro. (Tavosanis 206)

The issue of the influence Poliziano's Epistola had on Bembo turns out in consequence to be especially relevant not with regard to the idea of linguistic evolution - this can be found also in Landino - but because the letter accompanying the Raccolta Aragonese seems to somehow anticipate Bembo's historical vision. In fact, as stated by Nadia Cannata, in the age of Lorenzo de' Medici "coeve e parallele, convivono a Firenze due letture antitetiche della tradizione letteraria 
della città e della Toscana,"15 Landino's and Poliziano’s. The latter was also apparently shared by Lorenzo de' Medici himself, at least in an early stage of his literary career: as Roberto Cardini remarked, even if he did not assemble the anthology nor wrote its introductory Epistola, the Raccolta Aragonese bears his signature, and "documenta una ricostruzione della poesia Toscana diversa e avversa a quella della prolusione al Petrarca" ${ }^{" 16}$ by Landino.

The relationship between these two perspectives deserves a separate study. Focusing instead on their respective influence on Bembo's later codification, it should be remarked that the knowledge of the Epistola by the author of the Prose would entail his access to a text which, unlike Landino's proemio, was far from widespread. There are only three extant witnesses known to us, including an excerpt, and only one of the copies of the collection opens with the dedicatory letter, the other two witnesses being miscellanies. ${ }^{17}$ With regard to its diffusion this text simply cannot be compared to Landino's Comento, which was one of the most reprinted, read, and influential books in Renaissance Italy in general and in Bembo's Venice in particular, also because its Platonistic reading of Dante's masterpiece was very congenial to the late fifteenth-early sixteenth Venetian public. $^{18}$

Hypothesizing an influence of Poliziano's Epistola on the Prose, Tavoni does not provide any evidence about how Bembo might have known it. According to Paolo Bongrani, ${ }^{19}$ this passage of the opening of the third book of the Prose demonstrates that Bembo was familiar with Poliziano's letter:

... eglino tanto più chiari sono e illustri ciascuno, quanto più uno che altro leggiadri scrittori ha de' fatti e della virtù sua. Per che ragionevolmente Alessandro il Magno, quando alla sepoltura d'Achille pervenne, fortunato il chiamò, così alto e famoso lodatore avendo avuto delle sue prodezze; quasi dir volesse che egli, se bene molto maggiori cose facesse, non andrebbe così lodato per la successione degli uomini, come già vedeva essere ito Achille, per lo non avere egli Omero che di sé scrivesse, come era avenuto d'avere a llui. (Tavosanis 256) 
To support the idea that literature is better than the other arts, as it is the only one that really allows transmission of memory and fame, here Bembo recalls the anecdote of Alexander the Great on Achilles' tomb, calling him fortunate, since he had Homer as a poet to sing his praise. This same story is also evoked in the introductory Epistola of the Raccolta Aragonese, as an example of how much the Ancients valued poetry.

... il magno Alessandro, quando nel Sigeo al nobilissimo sepulcro del famoso Achille fu pervenuto, mandò fuori sospirando quella sempre memorabile, regia e veramente di sé degna voce:

Oh fortunato che sì chiara tromba trovasti, e chi di te si alto scrisse.

E sanza dubbio fortunato: impero ché, se 'l divin poeta Omero non fusse stato, una medesima sepultura il corpo e la fama di Achille arebbe ricoperto. (Breschi, "L'epistola" 217)

However according to Nadia Cannata, who wrote a study dedicated to the different recurrences of this anecdote, here Bembo is not quoting Poliziano's Epistola ${ }^{20}$ and we can conjecture that he went back to Petrarch's sonnet where the episode is also recalled, or directly to Petrarch's probable source, that is to say Cicero's Pro Archia. Bongrani's evidence thus seems inconclusive. ${ }^{21}$

The possibility of a connection between Bembo's Prose and the Raccolta Aragonese is also found in Mirko Tavosanis' work. Tavosanis advanced the hypothesis that when writing the Prose Bembo exploited a third collection of vernacular medieval poetry, besides the two already known, ${ }^{22}$ and by means of an analysis of the quotations from pre-Dantean poems in the Prose conjectures this source to be a copy of the Raccolta Aragonese (Tavosanis 85-97). Nevertheless, taking into account the peculiarities of the tradition that takes its origin from the Raccolta, the question of what parts of the original book were present in this supposed copy arises. Besides the fact that the epistola opens only one of the many witnesses of the collection, there is also the issue that most of the copies originating from the manuscript sent to Federico transcribe only a selection of poems from its first 
quires. We can thus agree with Tavosanis that the Aragonese was "la vulgata primocinquecentesca dei poeti antichi," as an anthology "di uso comune" at the beginning of the sixteenth century (Tavosanis 97), but the point regarding whether Bembo knew it in its entirety remains nevertheless problematic: several quotations analysed by Tavosanis came from poems copied in one of the last quires of the manuscript sent to Naples by Lorenzo de' Medici, but most of the copies originating from it do not transcribe this last section.

However that may be, in my view there is another passage of the Prose that could support the hypothesis of Bembo's knowledge of the Epistola, or at least of an excerpt of it, the same one transmitted by the manuscript Vatican 3213, compiled by Antonio Lelio between 1518 and 1527-28 (Frasso, Graffigna). This extract traces a short history of vernacular poetry, and in particular Tuscan poetry.

Fu l'uso della rima, secondo che in una latina epistola scrive el Petrarca, ancora appresso agli antichi romani assai celebrato; il quale, per molto tempo intermesso, cominciò poi nella Sicilia non molti secoli avanti a rifiorire, e, di quindi per la Francia sparto, finalmente in Italia, quasi in un suo ostello, è pervenuto.

Il primo adunque che dei nostri a ritrarre la vaga imagine del novello stile porse la mano, fu l'aretino Guittone, ed in quella medesima età il famoso bolognese Guido Guizinello, l'uno e l'altro di filosofia ornatissimi, gravi e sentenziosi; ma quel primo alquanto ruvido e severo, né da alcuno dolce lume di eloquenzia acceso; l'altro tanto di lui più lucido, più soave e più ornato, che non dubita il nostro onorato Dante padre appellarlo suo e degli altri suoi

miglior, che mai rime d'amore usor dolci e leggiadre.

Costui certamente fu il primo, da cui la bella forma del nostro idioma fu dolcemente colorita, quale appena da quel rozzo aretino era stata adombrata. Riluce drieto a costoro el delicato Guido Cavalcante fiorentino, sottilissimo dialettico e filosofo del suo secolo prestantissimo. Costui per certo, come del 
corpo fu bello e leggiadro, come di sangue gentilissimo, cosi ne li suoi scritti non so che più che li altri bello, gentile e peregrino rassembra, e nelle invenzioni acutissimo, magnifico, ammirabile, gravissimo nelle sentenzie, copioso e rilevato nello ordine, composto, saggio e avveduto; le quali tutte sue beate virtù d'un vago, dolce e peregrino stile, come di preziosa veste, sono adorne. Il quale, se in più spazioso campo si fusse esercitato, arebbe sanza dubbio i primi onori occupati; ma sopra tutte l'altre sue opere è mirabilissima una canzona, nella quale sottilmente questo grazioso poeta d'amore ogni qualità, virtù e accidente descrisse, onde nella sua età di tanto pregio fu giudicata, che da tre suoi contemporanei, prestantissimi filosofi, fra li quali era il romano Egidio, fu dottissimamente commentata. Ne si deve il lucchese Bonagiunta e il Notar da Lentino con silenzio trapassare: l'uno e l'altro grave e sentenzioso, ma in modo d'ogni fiore di leggiadria spogliati, che contenti doverebbono restare se fra questa bella masnada di si onorati uomini li riceviamo. E costoro e Piero delle Vigne nella età di Guittone furono celebrati, il quale ancora esso non sanza gravità e dottrina alcune, avvenga che piccole, opere compose: costui è quello che, come Dante dice:

tenne ambe le chiavi

del cor di Federigo, e che le volse, serrando e disserrando sì soavi.

Risplendono dopo costoro quelli due mirabili soli, che questa lingua hanno illuminata: Dante, e non molto drieto ad esso Francesco Petrarca, delle laude de' quali, si come di Cartagine dice Salustio, meglio giudico essere tacere che poco dirne.

Il bolognese Onesto e li siciliani, che già i primi furono, come di questi due sono più antichi, così della loro lima più arebbono mestiero, avvenga che né ingegno né volontà ad alcuno di loro si vede essere mancato. Assai bene alla sua nominanza risponde Cino da Pistoia, tutto delicato e veramente amoroso, il quale primo, al mio parere, comincio l'antico rozzore in tutto a schifare, dal quale né il divino Dante, per altro mirabilissimo, s'è potuto da ogni parte schermire. Segue costoro di poi più lunga gregge di novelli scrittori, i quali tutti di lungo intervallo si sono da quella bella coppia allontanati.

Questi tutti, Signore, e con essi alcuni della età nostra, vengono a renderti immortal grazia. (Breschi, "L'epistola" 218-20) ${ }^{23}$ 
When Bembo discusses in the first book of his Prose the loanwords adopted from Occitan, he cites seven poets he says have used them: Guinizelli, Cavalcanti, Cino, Onesto, Bonagiunta, Pier delle Vigne, Giacomo da Lentini. All of them are mentioned in Poliziano's Epistola, and there are no previous sources where these poets are associated as a group. Their association is in fact the result of the merging and integration of the two main kinds of sources from which a great part of Laurentian Florence's knowledge concerning the most ancient vernacular poetry came, and which shaped the perspectives of the Raccolta Aragonese in this regard: Petrarch's list of poets in his Triumph of Love on the one hand, and Dante's Comedy along with its exegesis on the other (Camboni).

It should be noticed that Bembo adds that this habit of borrowing words from Occitan was adopted by Boccaccio and Dante, but later; and hence, according to this passage, all the poets listed above precede Dante.

... molte altre voci di questa maniera in Guido Guinicelli si leggono, in Guido Cavalcanti, in messer Cino, in messer Onesto, in Buonagiunta, in messer Piero dalle Vigne, e nel Notaio, e in altri e poeti e prosatori di quella età. Passò questo uso di fine a Dante, e al Boccaccio altresì: tuttavia e all'uno e all'altro pervenne oggimai stanco. (Tavosanis 188-89)

As Dionisotti has said commenting upon the history of vernacular literature that Bembo includes in the opening section of the second book of the Prose, he did not distinguish among the vernacular poets that came before Dante. ${ }^{24}$ This refers to a section clearly influenced by the De vulgari eloquentia ${ }^{25}$ and mentioning many more poets than the passage above. Concerning Cino, however, in this introductory section of the second book of the Prose Bembo states that he was Dante's contemporary, and that he outlived his more famous friend. This appears to be in contradiction with the chronology implied in the passage concerning the Provençalisms. ${ }^{26}$ 
Such a contradiction is not a unique occurrence in the Prose, where there are some traces left of Bembo's previous inaccurate perspectives. For instance, in the first book Giuliano de' Medici explains that in the beginning the literary language of his native region was not so refined, and a positive development in this regard was already visible with Dante. In the first redaction of the Prose known to us Giuliano names Guido Guinizelli among the more ancient Tuscan poets who used plenty of unrefined words, though he was not Tuscan by any measure.

Era il nostro parlare negli antichi tempi rozzo e grosso e materiale, e molto più oliva di contado che di città. Per la qual cosa Guido Guinicelli, Guido Cavalcanti, Farinata degli Uberti e molt'altri, le parole del loro secolo usando, lasciarono le rime loro piene di materiali e grosse voci altresì. . . (Tavosanis 201$02)^{27}$

Subsequently, Bembo corrected this passage while revising the manuscript, deleting the name of Guinizelli, but when Giuliano states that Petrarch and Boccaccio did not have to use the language of Dante, and even less the language of those who came before Dante, Guinizelli is still mentioned among them. ${ }^{28}$

The list of poets in the passage concerning Provençalisms could be a similar, though less apparent, case: it may be a remnant of a previous draft, possibly from a period when Bembo was not yet aware of Dante's De vulgari, and when he was therefore relying on other sources to build his view of the past. It is no coincidence that we find it in the first book, and in the middle of the dialogue, not in an opening section. As a matter of fact, in its hypothetical source, Poliziano's letter, the proposed chronology is not completely clear. The first Tuscan poet to have started "outlining the sweet new style" is said to be Guittone (nevertheless judged as lacking "any spark of eloquence"). Then his contemporary Guinizelli is mentioned, and "after him" Cavalcanti: however, it is not so apparent for a reader that Cavalcanti was a more recent poet than Guinizelli. Afterwards the Epistola speaks briefly of Bonagiunta, the "Notar" Giacomo da Lentini and Pier delle Vigne, saying that they were contemporaries of Guittone. Then Dante and Petrarch are mentioned, and after them 
Onesto da Bologna and the Sicilians, in this case explicitly saying that they were "more ancient" than Dante and Petrarch; and finally, the Epistola touches upon Cino da Pistoia. Thus there is a chronological back-and-forth that could explain why a reader might find the timeline puzzling.

According to some scholars, ${ }^{29}$ the manuscript Vatican 3213, which is a well-known witness of the poems collected by the Raccolta Aragonese, had once belonged to Pietro Bembo. This hypothesis has been countered by others, and as Massimo Danzi remarks in his study of Bembo's library, there are no traces of Bembo's writing in it (which would be rather strange, if such a manuscript had been at his disposal). ${ }^{30}$ The first owner of the book was in fact Antonio Lelio.

Antonio Lelio lived in Rome, working in the same Curia where in March 1513 Pietro Bembo became secretary to Pope Leo X; he was a "protagonista di rilievo della vita culturale romana durante i pontificati di Giulio II, Leone X, Clemente VII,” who took Bembo's side during a 1519 dispute (Jossa). His compilation of the Vatican 3213 therefore strongly suggests that a copy of the Raccolta Aragonese, complete with its introductory Epistola, was circulating in Bembo's environment. As a matter of fact, another humanist that we know had access to a copy of Federico d'Aragona's book, Angelo Colocci, a shared acquaintance of both Lelio and Bembo, was on friendly terms with the latter from the end of the fifteenth century, and we know that some manuscripts passed from one to the other. ${ }^{31}$ Bembo was thus well placed to have access to the Raccolta Aragonese, and to at least a section of its dedicatory letter. He was, consequently, able to know the other reading of vernacular tradition in Laurentian Florence, and to be influenced by it in his way of applying the Golden Age-Decline-Revival model to vernacular literature. This is in fact how the above-quoted history of vernacular poetry traced by the Epistola concludes: saying that after Dante and Petrarch followed a multitude of poets, who never even came close to comparing with them. 
Segue costoro di poi più lunga gregge di novelli scrittori, i quali tutti di lungo intervallo si sono da quella bella coppia allontanati.

And this is the end of the history of vernacular literature included by Bembo in the opening section of the second book of the Prose:

Sono dopo questi stati, nell'una facultà e nell'altra, molti scrittori; vedesi tuttavolta che il grande crescere della lingua a questi due, al Petrarca e al Boccaccio, solamente pervenne; da indi innanzi, non che passar più oltre, ma pure a questi termini giugnere ancora niuno s'è veduto. (Tavosanis 213)

Besides conveying the very same meaning, the two passages as well as the general structure of the two texts are strikingly similar, and in both cases there is an understatement of the period between the Golden Age and the revival. Exploiting this paradigm, Bembo goes clearly beyond what the Epistola did, but the reuse of the same narrative applied in equal ways and also with identical devices must not be underestimated. In fact, it is precisely the deployment of such devices which allows Bembo to succeed in imposing his view.

As we have seen, Landino evokes artists and artistic development. Bembo does as well. The introductory section of the third book opens with the image of the many ancient works of art that can be seen in Rome and of the many modern artists who flock there to improve themselves by means of imitating the masterpieces of the past. Bembo thus takes his cue from the excellent results obtained by contemporary artists thanks to their close study and imitation of ancient works of art (among which he mentions as the finest examples Michelangelo and Raphael) to state that contemporary writers in the vernacular should also imitate the ancients. But in this passage he does not say who these ancients are.

Questa città, la quale per le sue molte e reverende reliquie infino a questo dì a noi dalla ingiuria delle nemiche nationi e del tempo, non leggier nemico, lasciate, più che per li sette colli, sopra i quali ancor siede, sé Roma essere subitamente dimostra a chi la mira, vede tutto 'l giorno a sé venire molti artefici di 
vicine e di lontane parti; i quali le belle antiche figure di marmo, e talora di rame, che o sparse per tutta lei qua e là giacciono, o sono publicamente e privatamente guardate e tenute care, e gli archi e le terme e i teatri e gli altri diversi edificij, che in alcuna loro parte sono in piè, con istudio cercando, e la forma di quelli nel picciolo spatio delle loro carte o cere rapportando, poscia, quando a fare essi alcuna nuova opera intendono, mirano in quegli essempi, e di rassomigliargli col loro artificio proccacciando, tanto più sé dovere essere della loro fatica lodati si credono, quanto essi più alle antiche cose fanno per somiglianza ravicinare le loro nuove; per ciò che sanno e veggono che quelle antiche più alla perfettione e consumation dell'arte s'accostano, che le fatte da indi innanzi. Questo hanno fatto più che altri, Monsignore messer Giulio, i vostri Michele Agnolo fiorentino e Rafaello da Urbino, l'uno dipintore e scultore parimente, l'altro e dipintore e architettore altresì; e hannolo sì diligentemente fatto che amendue sono ora così eccellenti e così chiari che più agevole è a dire quanto essi agli antichi buoni maestri sieno prossimani, che quale di loro sia dell'altro maggiore e miglior maestro. La quale usanza e studio, se, in queste arti molto minori posto, è, come si vede, giovevole e profittevole grandemente, quanto si dee dire che egli maggiormente porre si debba nello scrivere, che è opera così leggiadra e così gentile che niuna arte può bella e chiara compiutamente essere senza essa? . . . Il che se così è, che essere per certo si vede, facciamo ancor noi, i quali agli studi delle lettere donati ci siamo e in essi ci trastulliamo, quello stesso che far veggiamo agli artefici che io dissi; e per le imagini e forme che gli antichi uomini ci hanno dei loro animi e del lor valore lasciate, ciò sono le scritture, vie più che tutte l'altre opere bastevoli, diligentemente cercando, a saper noi bene e leggiadramente scrivere appariamo, non dico nella latina lingua, la quale è in maniera di libri ripiena, che oggimai vi soprabondano, ma nella nostra volgare; la quale, oltra che più agevolezza allo scrivere ci presterà, etiandio ne ha più bisogno. Con ciò sia cosa che quantunque dal suo cominciamento infino a questo giorno, come s'è detto, non pochi siano stati quelli che v'hanno scritto, pochi nondimeno si vede che sono di loro e in verso e in prosa i buoni scrittori. (Tavosanis 255-56)

The recommendation to follow in the footsteps of the ancients and Bembo's naming the models to be imitated for the vernacular can be found in different parts of the book, respectively III 1 and I 19. They are separated from each other, so that the above passage is somehow ambiguous. We could 
interpret it as having the same meaning as the following passage from Landino, one of the several where he states this key point of his thought: that is, in order to improve vernacular literature, vernacular authors should imitate ancient Latin ones.

Ma non sia alchuno che creda non solamente essere eloquente, ma pure tollerabile dicitore nella nostra lingua, se prima non harà vera et perfecta cognitione delle latine lettere. Perché nessuno dubita che ogni sermone è composto di parole et di sententie. Le parole sempre sono inepte sanza e precepti oratorii; et le sententie sono frivole sanza varia doctrina. Ma né arte rethorica, né doctrina alchuna ci può esser nota sanza lingua o greca o latina. Adunque almancho la latina ci e necessaria. Il che ha facto che molti nostri scriptori vacui di latine lettere et doctrina, benché lo 'ngegno et la exercitatione alchuna volta gli sobstengha, nientedimeno spesso rovinono, perché come ciechi procedono se el lume dell'arte non è porto. (Landino, Comento 255)

Bembo probably separates his call to imitate the ancients from the establishment of the vernacular models for the same reason he underplays the decline: to render the time lag between the historical trajectories proposed for Latin, vernacular, and the arts less noticeable, while exploiting the model of Golden Age-Decline-Revival and probably the hoariest topos of his age - the excellence of the ancients - to impose his viewpoint.

Bembo's inconspicuous way of stating that, indeed, after the great authors of the fourteenth century, vernaculars writers' quality worsened, could be influenced by Poliziano's analogous understatement, though due to different reasons. ${ }^{32}$ Undoubtedly, Bembo's view of how previous vernacular literature developed conforms to the perspective advanced in the letter accompanying the Raccolta Aragonese. The innovative aspect of his operation was to exploit the parallel (already hinted at by Landino) between Latin and vernacular literary evolution to impose the models to be imitated, while Poliziano's epistola, in the absence of such a parallel, does not really establish a canon, at least not an explicit one. 


\section{WORKS CITED}

Bembo, Pietro. Prose e rime. Ed. Carlo Dionisotti. 2a ed. accresciuta. Torino: Unione tipograficoed. torinese, 1978. Classici italiani 26.

Bongrani, Paolo. "Appunti sulle Prose della volgar lingua. In margine a una recente edizione." Giornale storico della letteratura italiana 159 (1982): 271-90.

Breschi, Giancarlo. "La Raccolta Aragonese.” Antologie d'autore: la tradizione dei florilegi nella letteratura italiana. Atti del Convegno internazionale di Roma, 27-29 ottobre 2014. Ed. Enrico Malato and Andrea Mazzucchi. Roma: Salerno Editrice, 2016. 119-56. Pubblicazioni del "Centro Pio Rajna". Sezione prima, Studi e saggi.

---. "L'epistola dedicatoria della Raccolta Aragonese. Edizione critica." "Per beneficio e concordia di studio": studi danteschi offerti a Enrico Malato per i suoi ottant'anni. Ed. Andrea Mazzucchi. Cittadella (PD): Bertoncello artigrafiche, 2015. 201-20.

Camboni, Maria Clotilde. "La formazione della Raccolta Aragonese.” Interpres XXXV (2017): 132.

Cannata Salamone, Nadia. "A dispetto della morte : il sospiro di Alessandro e la memoria della poesia. Una prima ricognizione delle fonti." In amicizia: essays in honour of Giulio Lepschy. Ed. Lino Pertile and Zygmunt G. Barański. Reading: University of Reading, Dept of Italian Studies, 1997. 52-82. Supplement to The Italianist ; no. 17.

---. "Il dibattito sulla lingua e la cultura letteraria e artistica del primo Rinascimento romano: uno studio del ms Vaticano Reg. lat. 1370.” Critica del testo VIII.3 (2005): 901-51.

Cardini, Roberto. “Landino e Dante.” Rinascimento 30 (1990): 175-90.

---. “Landino e Lorenzo.” Lettere Italiane 45.3 (1993): 361-75.

Cian, Vittorio. Un decennio della vita di M. Pietro Bembo: 1521-1531. Torino: E. Loescher, 1885.

Danzi, Massimo. La biblioteca del cardinal Pietro Bembo. Genève: Droz, 2005.

---. "Pietro Bembo." Autografi dei letterati italiani. Il Cinquecento. 1. Ed. Paolo Procaccioli et al. Roma: Salerno, 2009. 47-65.

Frasso, Giuseppe. "Per l'ordinatore del Vaticano lat. 3213.” Studi petrarcheschi 5 (1988): 155-95.

Gilson, Simon A. "La fortuna del Comento landiniano nel Cinquecento: lettori e commentatori danteschi." Per Cristoforo Landino lettore di Dante: il contesto civile e culturale, la storia tipografica e la fortuna del Comento sopra la Comedia. Atti del convegno internazionale, Firenze 7-8 novembre 2014. Ed. Paolo Procaccioli and Lorenz Böninger. Firenze: Le Lettere, 2016. 175-94.

---. "Notes on the Presence of Boccaccio in Cristoforo Landino's Comento sopra la Comedia di Danthe Alighieri." Italian Culture 23.1 (2005): 1-30.

Graffigna, Daniela. “Il manoscritto Vaticano lat. 3213.” Studi petrarcheschi 5 (1988): 196-289. 
Jossa, Stefano. "Lelio, Antonio." Dizionario biografico degli italiani. Roma: Istituto della Enciclopedia Italiana, 2005. Vol. 64: 327-30.

Landino, Cristoforo. Comento sopra la Comedia. Ed. Paolo Procaccioli. Roma: Salerno, 2001. Edizione nazionale dei commenti danteschi vol. 28.

---. Scritti critici e teorici. Ed. Roberto Cardini. Roma: Bulzoni, 1974. I critici italiani 1-2.

Ledos, Eugène-Gabriel. "Lettre inédite de Cristoforo Landino à Bernardo Bembo." Bibliothèque de l'Ecole des Chartes 54 (1893): 721-24.

McLaughlin, Martin L. "Humanist Concepts of Renaissance and Middle Ages in the Tre- and Quattrocento.” Renaissance Studies 2.2 (1988): 131-42.

---. Literary Imitation in the Italian Renaissance. The Theory and Practice of Literary Imitation in Italy from Dante to Bembo. Oxford: Clarendon Press, 1995.

Medici, Lorenzo de'. Opere. Ed. Attilio Simioni. 2nd ed., Bari: Laterza, 1939. Scrittori d'Italia 59.

Nolhac, Pierre de. La Bibliothèque de Fulvio Orsini. Paris: F. Vieweg, 1887.

Procaccioli, Paolo. "La redazione e la stampa del Comento. Tempi, modi, illazioni e implicazioni." Per Cristoforo Landino lettore di Dante: il contesto civile e culturale, la storia tipografica e la fortuna del Comento sopra la Comedia. Atti del convegno internazionale, Firenze 7-8 novembre 2014. Ed. Paolo Procaccioli and Lorenz Böninger. Firenze: Le Lettere, 2016. 137-53.

Pulsoni, Carlo. "II Comento sopra la Comedia di Cristoforo Landino e Pietro Bembo." Miscellanea di studi linguistici offerti a Laura Vanelli da amici e allievi padovani. Ed. Roberta Maschi, Nicoletta Penello, and Piera Rizzolatti. Udine: Forum, 2007. 419-26.

---. "Per la fortuna del De vulgari eloquentia nel primo Cinquecento: Bembo e Barbieri." Aevum 71.3 (1997): 631-50.

Siekiera, Anna. Bibliografia linguistica albertiana: 1941-2001. Firenze: Ed. Polistampa, 2004. Edizione nazionale delle opere di Leon Battista Alberti. Strumenti 2.

Tavoni, Mirko. Latino, grammatica, volgare: storia di una questione umanistica. Padova: Ed. Antenore, 1984. Medioevo e umanesimo 53.

---. "Le Prose della volgar lingua, il De vulgari eloquentia e il Convivio." Prose della volgar lingua di Pietro Bembo. Gargnano del Garda, 4-7 ottobre 2000. Ed. Silvia Morgana, Mario Piotti, and Massimo Prada. Milano: Cisalpino, 2001.

Tavosanis, Mirko. La prima stesura delle Prose della volgar lingua: fonti e correzioni. Con edizione del testo. Pisa: Edizioni ETS, 2002. Studi e testi di letteratura italiana 2.

Vecce, Carlo. "Bembo, Boccaccio, e due varianti al testo delle Prose.” Aevum (1995): 521-31.

---. "Bembo e Poliziano." Agnolo Poliziano poeta scrittore filologo. Atti del Convegno internazionale di studi (Montepulciano, 3-6 novembre 1994). Ed. Vincenzo Fera and Mario Martelli. Firenze: Le Lettere, 1998. 477-503. 
${ }^{1}$ McLaughlin, Literary Imitation (268); a quotation from Lorenzo's Comento follows.

${ }^{2}$ Besides McLaughlin, Literary Imitation (268), see also McLaughlin, “Humanist Concepts” (140-41).

${ }^{3}$ See especially Tavoni, "Le Prose della volgar lingua" and Pulsoni, "Per la fortuna".

${ }^{4}$ Tavoni, "Le Prose della volgar lingua" (131), Bongrani (289), and Tavosanis (97).

${ }^{5}$ See Ledos and Danzi, La biblioteca (322). Bembo's copy of Landino's Comento is Paris, Bibliothèque nationale de France, Rés. Yd 17. See also Landino, Comento (113-14, 137).

${ }^{6}$ Pulsoni, "II Comento sopra la Comedia".

${ }^{7}$ The annotations are quoted from Danzi, La biblioteca (322); a specimen of analogous Bembo's marginalia in another incunabulum now at the Bibliothèque nationale de France (Rés Yd 208, a copy of Dante's Convivio published by Filippo Bonaccorsi, Florence, 1490) is in Danzi, "Pietro Bembo" (63); those in Bembo's copy of the De vulgari eloquentia (Vatican City, Biblioteca Apostolica Vaticana, Regin. lat. 1370) can be examined in the digitized version of the manuscript avalaible online on the library's website.

${ }^{8}$ About such compilations see for instance Vecce, "Bembo e Poliziano" (484-85).

${ }^{9}$ See Cardini, La critica (119-25); for Alberti's promotion of the vernacular see Tavoni, Latino (41-72). Literature on Alberti's linguistic positions is abundant: see Siekiera.

${ }^{10}$ Cardini, "Landino e Dante" (184-87), Cardini, "Landino e Lorenzo" (367-68).

${ }^{11}$ Tavosanis (50), Vecce, “Bembo, Boccaccio” (529).

${ }^{12}$ Gilson, "Notes" (4-5).

13 “Agli italiani non si poteva imporre una unità linguistica toscana solo per le virtù naturali, che il Bembo apprezzava, del linguaggio toscano. In tanto questo linguaggio si era già imposto su ogni altro dialetto, in quanto era linguaggio di una nobile tradizione letteraria, di Dante, del Petrarca, del Boccaccio. Ma di questi documenti fondamentali, familiari a tutta Italia, bisognava ancora dimostrare la pertinenza a una tradizione, a una storia, e farne paragone, e di ciascuno spiegare i pregi e i difetti con i procedimenti critici stessi che erano stati applicati alle letterature classiche" (Bembo 4344).

${ }^{14}$ Tavoni, "Le Prose della volgar lingua".

${ }^{15}$ Cannata Salamone, "Il dibattito" (907).

${ }^{16}$ Cardini, "Landino e Lorenzo" (368).

${ }^{17}$ The only copy of the Raccolta aragonese that contains the letter is the manuscript Firenze, Biblioteca Nazionale Centrale, Palatino 204, copied after 1514, while the two miscellaneous witnesses are Firenze, Biblioteca Riccardiana, Riccardiano 2723 (late XV century) and Città del Vaticano, Biblioteca Apostolica Vaticana, Vaticano lat. 3213 (early 
XVI century), where there is only an excerpt. For details about the tradition of the Epistola, a new edition and a bibliography, see Breschi, "L’epistola".

${ }^{18}$ Gilson, "La fortuna" (178 in particular)

${ }^{19}$ Bongrani (289).

${ }^{20}$ Cannata Salamone, "A dispetto della morte" (73).

${ }^{21}$ In support of his hypothesis, Bongrani also produces some annotations by two of Bembo's editors, Dionisotti and Pozzi: but in reality both compare Bembo's positions to what is written in the Epistola without stating that he knew it.

${ }^{22}$ That is to say, a manuscript of him that we still have (today Città del Vaticano, Biblioteca Apostolica Vaticana, Vaticano lat. 3214), and another for which we have a copy/collation by Lorenzo Bartolini (Firenze, Accademia della Crusca, MS 53).

${ }^{23}$ The extract, quoted from Breschi's edition, is nevertheless almost identical to the text given by the manuscript Vat. lat. 3213 , as the latter "si distingue per un numero esiguo di omissioni ed errori" and is "il manoscritto relativamente più corretto (Breschi, "L'epistola” 214-15).

24 “Come già nell'elenco del libro I, cap. X, il Bembo non fa qui differenze di generazioni e di scuole fino al Cavalcanti incluso. Numericamente, l'elenco rappresenta un buon passo avanti rispetto alle precedenti rassegne dell'antica poesia volgare, ma esso anche rivela una certa impazienza: il Bembo era troppo impegnato in una ricerca linguistica e metrica valida per l'età sua, per poter anche guardare al passato remoto con distacco e insieme puntiglio di storico. Così anche qui, dove la lezione del De vulgari eloquentia è pure evidente, di una lezione si tratta imperfettamente appresa. Le distinzioni che l'opera dantesca suggeriva sono trascurate senza apparente motivo. ... Sono invece mescolati i poeti siciliani e meridionali della prima scuola . . . con i poeti toscani . . . e fra questi anche non è fatta distinzione d'età né di scuola" (Bembo 129 note 1).

${ }^{25}$ Tavosanis (110-11); Pulsoni, "Per la fortuna" (635-36).

26 "Vennero appresso a Dante, anzi pure con esso lui, ma a llui sopravissero, messer Cino, vago e gentil poeta, e sopra tutto amoroso e dolce, ma nel vero di molto minor spirito; e Dino Frescobaldi poeta a quel tempo ancora egli assai chiaro ..." (Tavosanis 212).

${ }^{27}$ The incorrect opinion that Guinizelli was from Florence was widespread - it can be found even in Landino's Comento (Landino, Comento 1433), which is also contradictory in this regard because in another passage Landino correctly states that Guinizelli was from Bologna (Landino, Comento 1224). This passage seems to have been corrected while the Comento was being printed (see Procaccioli 144-45). 
${ }^{28}$ Tavosanis (206). More embarrassingly, in both passages among the names of "pre-Dantean" poets the name of Farinata degli Uberti remains unchanged; as far as we know he had never written a single line, and instead Bembo had mixed him up with his son, who according to Bembo's manuscript later copied by Bartolini composed a single sonnet (Tavosanis 110, note 40).

${ }^{29}$ Cian (84), Simioni (Medici II, 337).

${ }^{30}$ Nolhac (310-11); Danzi, La biblioteca (331).

${ }^{31}$ Danzi, La biblioteca (31 note 63); on Colocci's access to the Raccolta see Camboni (2, 25 and note 49), also for further bibliography; for his acquaintance with Lelio see Jossa (328)

${ }^{32}$ Poliziano was declaring that a fair share of the poems in the anthology that he was introducing were in fact not so good: about this one as well at least another contradictory aspect of the Raccolta Aragonese, already remarked by Breschi, "La Raccolta Aragonese”, see Camboni. 